\title{
A Phenomenological Study on the Challenges and Problems of New Social Studies Teachers
}

\author{
Jay Morilla De Loreto ${ }^{1} \&$ Arvin Demate Jr. ${ }^{2}$ \& Crizmark Dela Cruz $^{3} \&$ April Joy Periña ${ }^{4} \&$ \\ Maica Paril ${ }^{5} \&$ Jomarie Esteves $^{6}$
}

1,2,3,4,5\&6 Northern Quezon College Incorporated (NQCI), Quezon Province, Philippines Correspondence: Jay Morilla De Loreto, Northern Quezon College Incorporated (NQCI), Quezon Province, Philippines.

Email: jaydeloreto@yahoo.com.ph

doi: 10.23918/ijsses.v6i2p23

\begin{abstract}
To enhance the teaching-learning process in Social Studies, this study explored the challenges and problems encountered by the new graduate Social Studies Teachers' at the selected private schools in one of the provinces of the Philippines. Using the qualitative methodology, the researchers interviewed five (5) participants who were purposively selected using the identified criteria. A series of procedures were employed that helped to code and categorize the details of participants' narratives and stories. To get the themes of their accounts, the analyses of meanings were performed. Findings revealed five (5) important themes that may help teachers and educators to enhance the Social Studies Education. Finally, a discussion of concepts and major recommendations was presented in light of the recently established facts from literature and studies.
\end{abstract}

Keywords: Social Studies, Challenge, Problem, New Graduate, Teacher, Phenomenology, Teaching-Learning Process, Education

\section{Introduction}

Social Studies has been regarded as a very important curriculum component that trains individuals to become responsible citizens. It prepares students for the realities of life as social beings. For instance, Alabas (2018) argued that Social Studies class encompasses the concepts of patriotism, economic productivity, and social harmony. Its relevance can be observed as it makes students knowledgeable and aware of their surroundings, upholds values formation, promotes cultural sensitivity, advances community participation, and gives a broader perspective on local, national, or global issues (Crisolo, Camposano \& Rogayan, 2017).

Ideally, Social Studies teachers as responsible citizens play a significant role by employing effective learning strategies in their respective lessons to teach the "ideals" of society (Eisner as cited in Kenyon, 2018). In doing this, students may have the time to explore things as they are given the avenue to learn more about the subject since it is found out that teachers' instructional strategies are significantly related to students' learning styles. Despite these realizations, teaching Social Studies is still considered as a challenging task. In fact, Tena (2019) reported that students are not participative in activities, often distracted by their gadgets, and lack the motivation to learn the subject.

Motivation is a key factor of success in teaching and learning. As Dislen (2013) stated, some problems in the teaching-learning process may appear if students are not motivated to learn. He added that without the eagerness to learn, achieving the learning outcomes will be so impossible. Thus, there will be minimal 
benefits gained from attending classes in Social Studies. In the study of Kiliçoğlu (2018) for example, the findings show that the belief in learning Social Studies lessons was predicted by students' intrinsic motivation, extrinsic motivation, and achievement. Furthermore, Mathe and Elstad (2018) found out that a strong desire to learn Social Studies is strongly connected with students' perceptions of the relevance of the lessons.

In the Philippines, the 1987 Philippine Constitution requires every educational institution to promote quality education for all (De Leon \& De Leon, 2014). Thus, the Philippine Government through the Department of Education (DepEd) formulates better policies that shape the landscapes of the Basic Education Programs today, especially on the matters related to teaching and learning. As evidence, the Philippine Professional Standards for Teachers (PPST) was recently instituted to uplift the quality of teaching in the country (DepEd, 2017). In its salient provisions, teachers are categorized into four, to wit: beginning teachers; proficient teachers; highly proficient teachers; and distinguished teachers. Each of these categories has performance indicators that teachers need to satisfy or meet based on the domains and strands of the PPST. As new graduates from College, these teachers are considered as "Beginning Teachers" who should have the following attributes: (a) have a strong understanding of their areas of specialization; (b) have acquired the needed knowledge, skills and values that support the process of teaching and learning; and (c) have ways on how to strategize their lessons to promote learning (DepEd, 2017). From these attributes, there is an implied meaning that teachers should be deep understanders of students and they shall keep working along with the set standards to ensure quality.

\subsection{Background of the Study}

Citizenship education has been the heart of Social Studies subjects. The United States (US) National Council for Social Studies (NCSS, n.d.) reported that this subject draws its content from the various disciplines of Humanities and Social Sciences to promote civic competence. Using the student-centered approach to learning, Kenyon (2018) advocated that this subject will enable students to embrace the duties of citizenship through the expansion of their knowledge, skills, and abilities as the "next generation". With its first appearance as part of the Basic Education Curriculum in the US, the Council also emphasized that Social Studies makes students aware of the realities thus making them appreciative of their roles in nationbuildingg. In this way, a society creates means towards making each learner as responsible citizens.

The advent of the K to 12 Curriculum in the Philippines paves the way for a more comprehensive Social Studies Curriculum. With the commitment to achieve excellence in its performance, the Department of Education (DepEd) together with the different government agencies, private institutions as well as experts in the field spearheaded the changes in the field (Combalicer, 2016). With this, a new Social Studies Framework was developed and sets of competencies were recommended to achieve the attributes of the 21st-century learners. This Framework aims to mold functional literate Filipinos. In this regard, the new curriculum aimed to mold students as citizens who are analytical and critical thinkers, reflective, responsible, environmentally responsible, productive, patriotic, and humanitarian (DepEd, 2013). It also expands students' perspectives on national and global concerns with deep-seated appreciation on the importance of historical and societal concerns. 
The concerns of the new curriculum are so much related to the concerns of teachers in the field of Social Studies. The new framework highlights the three important theories of learning such as constructivism, collaborative learning, experiential learning, and contextual learning. It also encourages teachers to the use of different approaches like thematic- chronological, conceptual, investigative, and integrative approaches. Since Social Studies is characterized as a very broad subject (Berson, Cruz, Duplass, Johnston $\&$ Adler, 2002), the need to use interdisciplinary and multidisciplinary approaches were emphasized as relevant components of teaching the new curriculum.

Various researches and reports had been conducted and gathered to guide teachers in strategizing their lessons in the subject. As a support to the development of the teaching-learning process in Basic Education, this research was anchored on the Basic Education Research Agenda (BERA) which highlights the teaching-learning process as a priority research theme (DepEd, 2016). It is also anchored on the advocacies of the Regional Development Council of Region IV-A (Provinces of Cavite, Laguna, Batangas, Rizal and Quezon) through its Regional Development Research Agenda (RDRA) 2018- 2022 which listed education as one of the top priority research areas to address the development challenges on low achievement rate among others (Regional Development Council [RDC], 2018).

To understand more about the success of the Social Studies Program in the Province, this research explores the experiences of the selected new graduate teachers at the selected private schools. It focuses on the problems and challenges of the teaching-learning process and their impacts on students' learning, teachers' ways on how to handle these concerns, and personal motivation to pursue their careers and duties as Social Studies teachers. This research is of great significance to the program administration of private high schools and Teacher Education Institutions (TEIs) to further enhance the preparation and training of preservice teachers and in-service teachers of Social Studies subjects.

\subsection{Statement of the Problem}

Maximizing learning opportunities will not be possible without effective and motivated teachers (Hammond, 2000). As Rice (2003) concluded, the quality of learning highly depends on the preparation of teachers, their training, and coursework. Thus, this research which aimed to help Social Studies teachers and educators was conducted to deeply understand the phenomenon by exploring the participants' narratives.

Specifically, this study sought to answer the following questions:

1. What challenges and problems do the teacher-participants encounter in teaching Social Studies subjects?

2. How do those challenges and problems affect the teaching-learning process?

3. How do they manage those challenges and problems?

4. What inspires them to overcome the challenges and problems in teaching?

5. What implications can be drawn from the study to enhance the teaching-learning process in Social Studies? 


\subsection{Scope and Delimitation}

The study was conducted in one of the provinces of the Philippines in the School Year 2018- 2019. Teachers' experiences with regards to the challenges and problems in teaching Social Studies subjects were explored with the use of teachers' accounts as inputs of the study.

As to its limitation, this study did not include all Social Studies teachers who are teaching in universities or colleges. This study only focused on the experiences of Social Studies Teachers in the High School level. Also, the findings of this research will not be generalizable to all Social Studies teachers due to the number of participants and the nature of the qualitative-phenomenological approach. However, the contribution of this study is highly essential with its commitment to explain the teachers' challenges, problems, and aspirations to pursue by presenting a holistic view of the teachers' experiences in teaching Social Studies.

\section{Review of Related Literature and Studies}

For a greater understanding of the challenges and problems in teaching Social Studies, the reviewed related literature and studies were organized. The thematic organization method was utilized to present the relevant information on the research topic. Thus, this review is divided into sections that help the readers to easily grasp that established information that may partly explain the concerns on teaching and learning. Specifically, it presents the details of problems on student motivation, lack of instructional materials and preparation, lack of training in teaching, strategies to promote learning in Social Studies, and the roles of teachers as a responsible professional.

With the help of the relevant studies and reports on the research topic, the researchers became guided by the concepts, processes, and ideas on writing this phenomenological study. It also helps the researchers for a deeper analysis of the meanings of the teacher- participants' accounts through a variety of subjective experiences as shared in the previously published research articles. The empirical evidence presented also contributed to this study since they offered a venue to critically examine facts using the objectivity reality.

\subsection{Challenges and Problems in Teaching Social Studies}

Teaching although enjoying is a challenging task because it requires a complex set of roles. For instance, Okechukwu (2015) presented that a teacher should meet a lot of expectations such as mastery and good delivery of lessons, providing feedback to students and parents, coping with the changing world of educational technologies, and learning how to address maladaptive behavior in the class. These activities are often challenging because the teachers' role is not so simple. Szucs (2017) reported that students have very high expectations for their teachers. Her research found out that students would like teachers who are willing to acquire more learning in the subject. Other students also shared that great teachers are those who provide attention to students, especially to those at risk, treat students fairly, and respect opinions and beliefs.

The aforementioned characteristics of teachers are elaborated by Terronez (2017) in his presentation in TED Talks at Santo Domingo. Some of his researches highlight are connotatively presented as follows: (a) a great teacher eats apples; (b) a great teacher is chill; (c) a great teacher is not a teacher; (d) a great 
teacher is humble before his or her students; (e) a great teacher knows that students have lives outside the classroom; (e) a great teacher sings; and (f) a great teacher thinks like a kid but acts like an adult. However, there is a need for an extensive Teacher Education Program (Ulla, 2016), along with pre-service teachers' personal motivation to have these attributes (Lopez \& Irene, 2018).

In spite of these "ideal" attributes of a teacher, sometimes schools do not pay attention too much on looking at this very important element of teaching and learning. For instance, Biku, Demas, Woldehawariat, Getahun, and Mekonnen (2018) reported an instance where teachers teach without any pedagogical training. In their study, they found out that this practice negatively affects learners' performance in class. This instance resulted in unorganized lessons, poor time management, no clear target outcomes, and poor evaluation of students' performance. Nevertheless, skills in facilitating the learning process and organizing the learning spaces of students are crucial aspects of teaching (Hannah, 2013).

\subsubsection{Students' Motivation}

Progressive education as advocated by John Dewey argued that a teacher-centered approach to learning should be replaced with student-centered ways of teaching (Williams, 2017). Since it views schools as doors of opportunities for students to immerse in a variety of activities such as collaborative learning, experiential learning, open schools, among others (Multinovic, 2009), it may be a means to greater motivation and achievement of students. In the context of the present study, the motivation of students is very important to consider.

There are numerous studies and reports which are available online on a lack of students' motivation. One of these is the report of Carnegie Mellon University which identified six (6) important scenarios. They are as follows: (a) learners don't see the relevance of the subject or the lessons; (b) they lack self- motivation to improve their performance; (c) they are not motivated due to lack of organization and rewards system in a class; (d) the classroom climate is perceived to be unhelpful; (e) students have other activities that take their time for studies; and (f) possibly, students have personal problems, or have disability that negatively affects their eagerness to learn (Elberly Center, 2019). In her study, Dislen (2013) presented a very detailed concept of motivation, especially those variables which negatively affect related the students' motivation. Some of them are the overloaded contents of the curriculum guide, health problems, lack of materials, teacher-centered method, lessons are boring, noisy classrooms, and lack of comprehension.

The present study is of great interest to learn from the comparisons of the researches conducted in the last 30 years as well as from the contemporary researches on students' perceptions of Social Studies and Social Studies classrooms. Historically, Social Studies was perceived by the students as the least relevant and interesting subject in the curriculum (Shaughnessy \& Haladyna, 1985). Also, it was reported that students considered that this subject was not an enjoyable part of the curriculum. In fact, Schug et al. (1982) presented that many students found the contents of this subject as uninteresting, not related to their experiences, and too historically detailed. Over the years, the motivation of students towards Social Studies is becoming different. A lot of researches could be cited that link the changes in education to perceived roles and the importance of students. 
With their qualitative study on the opinions of students on history subject as part of the Social Studies curriculum, Akengin and Cendek (2017) found out that the participants' accounts reveal a positive image of Social Studies. The conception of the participants on History as a discipline of Social Studies was positive. They also realized that history was relevant to them since they can relate their own experiences to the lessons. The study of Borhaug and Borgund (2018) found out that Social Studies is a motivating subject since it opens opportunities for students to develop self- regulation. Here, the authors noticed that student- participants felt a more supportive environment for them to share their emotions although previous researches found out that there was a common understanding that this subject focused much on memorization (Solhaug \& Borhaug, 2012). With these evidences, it is noticeable that there is an improvement on how Social Studies Education has been taught and implemented in schools. However, since education is a continuous process of learning, the learners' motivation as an important element (Kılıçoğlu, 2018) should always be considered. This present study, therefore, is a good input to carry out this scheme.

\subsubsection{Teachers' Concerns}

Aside from lack of students' motivation, challenges and problems such as gaps in the pre-service education, lack of confidence to teach the subject and pedagogical content knowledge on the subject, and lack of instructional materials negatively affect the performance of teachers. There is a multitude of studies that took these as areas of inquiries.

\subsubsection{Lack of Pedagogical Content Knowledge (PCK) on the Subject}

In her analysis, Tabenaum (2015) found out that teacher candidates had a limited understanding of the roles of education in society. With this, she suggested that Teacher Education Programs should be enhanced to make the teacher candidates prepared for their profession. Another study looked into the content knowledge of in-service and pre-service teachers on geo- literacy. Here, Memişoğlu (2017) found out that the participants don't have enough knowledge of geo- literacy. When the participants were asked about their opinions about the topic, much of their explanation merely focused on conceptual information. They also shared that they were not capable of association, relation, critical geography dimension, and spatial perception skills. In fact, there are many researches in the United States which presented that many teachers lack the needed pedagogical content knowledge (PCK) like the works of Henry, Paterson, Campbell and Yi (2013), Ingersoll, Merrill and May (2014), Kilink et al. (2016), and Kopish (2016).

In Australia, Hudson, Hudson, Weatherby-Fell, and Shipway (2016) investigated the status of preservice teachers' confidence against the Australian Professional Standards for Teachers (APST). The findings of their study revealed that the respondents lacked confidence in different areas of the professional standards such as (a) confidence to employ strategies to maximize the participation of learners with disability, (b) confidence to show understanding of aboriginal students, (c) confidence to make parents participative in the school activities, and (d) confidence to communicate the learning progress of each student. Like the previous study, it calls the universities and colleges to prepare future teachers with practical applications of educational theories on the area of students' confidence. In Ohio, California however, middle- school teachers reported that they were confident in their training to teach students (Ochanji et al., 2016). 


\subsubsection{Lack of Instructional and Learning Materials}

The importance of these materials is inevitable in the teaching-learning process. Basilan (2018) emphasized that these are requisites of effective instruction to deliver lessons effectively. She specifically detailed the importance of these to learners such as support to learning the contents of lessons, engagement of students to apply the lessons and support the phase of student evaluation. Nevertheless, aside from the lack of students' attention and teachers' preparation, Social Studies teachers encounter problems in making the learning areas as conducive learning spaces. For instance, the study of Kece (2013) reported that there are common problems in Social Studies classrooms. Some of those are as follows: (a) lack of textbooks; and (b) not conducive physical atmosphere. This finding was also true in the Philippine scenarios. Even after the advent of the major curricular reform in the country which is the institution of the Enhanced Basic Education Act of 2013 or the "K to 12 Law", still, the Department of Education (DepEd) has to take a closer look on the adequacy of learning and teaching materials in some areas of the country (Combalicer, 2016).

The study of Memişoğlu (2015) highlighted the importance of Social Studies as a subject that supports Conflict Resolution. However, in this analysis, it was also found that Social Studies teachers lacked instructional materials that make the instruction less effective. In Nigeria, Ogaga, Wallace, and Benson (2016) studied the possible effects of instructional materials on processes of teaching and learning in Social Studies. Descriptive and inferential analyses were made and the study revealed the following facts: (a) the majority of the respondents agreed that instructional materials influence students' academic performance; (b) these materials increase the rate of learning retention; (c) appropriate selection of materials is important or relevant in teaching the subject; (d) adequate instructional materials contribute to the success of the lesson thus making the lesson objectives met after the session. Therefore, this study reiterated that there is a need to improvise learning and teaching materials so everyone has the chance to maximize the learning opportunities (Kolo as cited in Ogaga, Wallace, \& Benson, 2016).

To at least minimize the problems on instructional materials and other learning resources, studies and literature proposed some important projects or concepts. Basilan (2018) for example reported that due to the advent of the "K to 12 Basic Education Program" in the Philippines, many schools in the country encounter the scantiness of materials as a problem in the teaching-learning process. As anchored on the findings of her research, it was proposed to maximize the available online resources on the Internet. With this, she proposed an offline digital archive which was named "Libro ni Bonsai". This is a free application on a mobile phone that could help teachers to make the learning process more effective. In Turkey, Akman (2016) also confirmed that Social Studies teachers need archives for the subject to support effective learning. In this way, teachers, educators, researchers, and students may have the necessary resources in understanding social phenomena that require historical interpretation of sociological, political, economic, and cultural scenarios.

\section{Research Design}

In this study, researchers utilized the qualitative methodology to come up with the findings of the challenges of beginning teachers. It is established that this is the most appropriate methodology that approaches the research problems. The qualitative methodology describes the events holistically and 
realistically in a natural environment (K1liçoglu, 2018). It is anchored on the principle that reality is viewed by different persons in different ways. Cropley (2019) discussed that every person constructs a personal and individual view of events based on his or her interactions with other people. Specifically, this study used the phenomenological research design which aims to explore the lived- experiences of the research participants. Exploring the lived- experiences Husserl's point of view (popularly known as the transcendental phenomenology), is all about eliminating any prejudgement or presupposition about a phenomenon (Moustakas, 1994). In this design, the interpretation is based on the challenges encountered by the participants as they face their duties as Social Studies Teachers. Furthermore, a mere description of experiences as advocated does not adequately depict the phenomenon. As a matter- of- fact, Todres and Wheeler (as cited in Dowling, 2007) argued that hermeneutics should be added to have a deeper sense of meaning based on the lived- experiences of the participants. Furthermore, Astalin (2013) asserted that a phenomenological study does not give definitive explanations but it highlights insights that can be learned from a phenomenon.

\subsection{Participants of the Study}

In the selection of the participants for this study, purposeful sampling was used. This type of sampling is widely used to select and identify information-rich cases which is related to the phenomenon (Patton as cited in Palinkas et al., 2015). Specifically, this study utilized the criterion sampling strategy to identify the research participants who are qualified based on the given criteria. The researchers were guided by the work of Creswell which identified that the minimum number of participants should be 10 or less than ten (Onwuegbuzie \& Collins, 2007).

For this study, the criteria for the selection are as follows: (a) new graduate from a recognized Teacher Education Institution; (b) a Bachelor's Degree Holder major in Social Studies Education; (c) teaching Social Studies in a public or private secondary school; (d) willing to participate in the study; and (e) can articulate his or her significant experiences.

Table 1. Participants' Information

\begin{tabular}{|c|c|c|c|c|}
\hline Pseudonym & Gender & Age & Graduation year & Institutional Type \\
\hline Teacher Andrew & Male & 21 & 2018 & Private-Sectarian School \\
\hline Teacher Bryan & Male & 21 & 2018 & Private- Sectarian School \\
\hline Teacher Chris & Male & 21 & 2018 & Private Nonsectarian School \\
\hline Teacher Denver & Male & 20 & 2018 & Private Nonsectarian School \\
\hline Teacher Esteve & Male & 21 & 2018 & Private Nonsectarian School \\
\hline
\end{tabular}

\subsection{Means of Gathering the Lived- Experiences}

This study used in-depth interviewing and storytelling to gather the narratives or accounts of the research participants. Using an interview protocol and with a strong collaboration with the participants, the researchers managed all the fieldwork and ensured the depth and breadth of the study. Interview is considered as the most common means of data gathering qualitative researches (Grossoehme, 2014). In phenomenological interviewing, the researchers treated the activity as an active learning process with the 
research participants. This allowed them to explore the challenges encountered by the participants. To ensure that all the dimensions of experiences can be gathered, the interviewers asked follow- up questions. As proposed by Bevan (2014), in phenomenological interviewing, a judgment should be made to identify and clarify the structures of the participants'experiences.

An interview protocol was utilized as an instrument of this research. This tool consists of specific questions that are anchored on the specific statement of the problems. The three important validation concepts were considered such as criterion validity, construct validity, and content validity. With this, the collection of data with the research participants are well-guided with the researchers as active listeners and investigators of the phenomenon.

\subsection{Stages in Doing a Phenomenological Study}

Drawing from the transcendental and hermeneutic phenomenology, this study followed the following stages: (a) select the participants based on the set criteria; (b) establish strong connection with the participants; (c) conduct an in-depth interview coupled with storytelling; (d) conduct the analysis of meaning through initialization, construction, rectification, and finalization.

Vaismoradi, Turunen, Jones, and Snelgrove (2016) outlined the phases and stages of theme development. As adopted in this study, the researchers transcribed the accounts and highlighted meaning units through the coding process. This stage is the initialization phase that also requires the writing of reflective notes to look for possible categories that may arise in the process. In the construction phase, the researchers compared and classified the codes into categories. To check whether the categories are already eligible for thematic construction, the rectification phase was done. The researchers immersed themselves with the data and moved away from the data for quite a time to have the opportunity to move back and forth between the methods and the findings of the study (Morse, Barrett, Mayan, Olson, \& Spiers, 2002). Here, the amalgamation of the categories was developed as themes. The last phase is the finalization stage. Researchers developed the storyline to present the findings of this study. Here, some verbatim accounts of the participants were quoted. This strategy helps to enhance the readability of the research, deepens the understanding of the findings of the study, and provides additional explanation and evidence to the research (Corden \& Sainsbury, 2006).

\section{Findings}

After various phases of theme development, the researchers identified five (5) important themes on the challenges encountered by the new graduate Social Studies teachers. The following themes were presented as follows: (a) the teachers' burden; (b) lack of pedagogical content knowledge; (c) the shortchanged students; (d) the needs-strategies-competencies alignment; and (e) teachers as catalysts of change.

\subsection{The Teachers' Burden}

The new graduate Social Studies teachers have realized so many things in teaching. They shared that the curriculum itself is a problem. They stated that their schools are lacking with the needed instructional materials like books and modules. For instance, Teacher Bryan shared that: 
"Some of the textbooks are outdated and not aligned with the new curriculum. Also, I noticed that sometimes, it's not easy to achieve the learning competencies for every topic."

In a school, the curriculum does not only pertain to the subject offerings. It also includes essential materials to support the teaching-learning process. Thus, Bilbao, Iringan, and Javier (2008) called it a 'supported curriculum'. Some examples are textbooks, modules, computers, audiovisual materials, and other learning resources. Samuel (2009) asserted that the utilization of instructional materials makes the learners exposed to the lessons and enrich their learning. Furthermore, he emphasized that instructional materials significantly contribute to the learning process.

Another thing that is noticeable among participants' narratives is the problem on how to engage students in the learning process. They mentioned that motivating students is not an easy task. They revealed that many of their students are inattentiveness. For instance, Teacher Andrew encounters problems with how he will make students attentive. He shared:

"They are so noisy. There are times in class that they don't listen and they keep chatting with their classmates. Because of their behavior, I can say that it is just like they are in the public market. They are doing their businesses while in my class."

Teacher Andrew's narrative signifies that teaching Social Studies is quite a challenging task for a new graduate teacher. In connection to this, Teacher Denver has shared an important insight. He mentioned:

"As a teacher, creating intrinsic motivation is a problem. It is because if the students are not motivated to do or even participate in the study or in-class activities, it is very hard for me to facilitate the learning process."

With the aforementioned challenges in problems in teaching Social Studies subjects, the new graduate teachers have realized that achieving the highest level of learning in Social Studies requires patience. For them, teaching Social Studies subjects is not only concentrated with facts, memorizing dates, and names; it is all about enlightening minds, showing the reality, and talking about the past to provide solutions.

\subsection{Lack of pedagogical content knowledge}

Teaching Social Studies does not only require subject expertise. In Basic Education, the knowledge on how to facilitate the learning process is very important. As the participants mentioned, students are becoming inattentive not just because students are naturally inattentive. For them, teachers should have high regard on how they see their classroom management styles. With this, Teacher Chris shared:

"I think, the teaching strategies or techniques that I employed were not suited and did not address the interest of my students."

In teaching, pedagogical content knowledge is very important. The Department of Education (DepEd, 2017) sets the national standard for teacher quality that emphasized the need to make teachers adept on 
how to ensure that learning takes place inside and outside of the school. In this regard, most of the participants in this study agreed with Teacher Bryan's narrative. Teacher Bryan mentioned:

"As a Social Studies teacher, I should be more knowledgeable than the students in terms of content knowledge."

On the other hand, Teacher Andrew reiterated the duties of teachers that must be done to ensure learning. He clarified that problems in facilitating the learning process may stem from a teacher-centered approach to teaching. Thus he argued that teaching should not be centered on teachers. He emphasized that teachers must think that students should be better-off and should learn more to understand the world. He expressed his thoughts in the following lines:

"When we talk about the subjects, of course, my students need to understand what I am teaching. So, it means that I cannot proceed to another lesson until there are students who cannot understand the lesson or the discussion."

From the aforementioned narratives, it is very clear that the participants of this study have a strong awareness that "the teachers' burden" or the problems in teaching Social Studies subjects may stem from lack of pedagogical content knowledge in facilitating the learning process.

\subsection{The Shortchanged Students}

The Philippine Government through the Department of Education (DepEd) is tasked to ensure that the right of all Filipino learners to quality education is enjoyed. This iniative highlights the constitutional mandate that requires government agencies and private institutions of learning to ensure that all students and pupils receive quality education (De Leon \& De Leon, 2014). In this study, however, the teacherparticipants shared that quality education is difficult to achieve if students are not participative in lessons. When asked about the effects of his problems in teaching Social Studies subjects, Teacher Bryan pinpointed that it is somewhat related to the acquisition of knowledge. He said:

"The problem affects the acquisition of knowledge. It is not easy to teach Social Studies subjects. Due to this, sometimes, learning competencies cannot be achieved."

Also, Teacher Denver viewed that problems such as lack of instructional materials in teaching and lack of pedagogical content knowledge affect his class. He discussed that these problems affect instruction because it causes low participation and slow pacing in facilitating the learning process. Teacher Andrew is also aware that these problems may not give students the chance to learn the very important concerns in Social Studies. He mentioned:

"Because of these problems, there is a tendency that students will not learn the subject."

With the participants' accounts, it is very clear that students are becoming shortchanged. They can not learn the "must be learned" content of the curriculum. Colceru (2013) asserted that Social Studies 
Education is used as a tool to "create good citizens". With this fact, the teacher-participants are aware that the failure to provide adequate education may have a big impact on how the students will see the things and phenomena around them.

\subsection{The Needs-Strategies-Competencies Alignment}

The teacher-participants have shared a common understanding of concepts for better facilitation of the learning process. For them, the problems can be solved when they will align the three most important parts of the curriculum, to wit: learning needs; teaching strategies; and desired learning competencies. Building a good relationship with their students is considered important to address concerns. However, teachers need not forget that teaching entails a variety of ways to engage students. In this regard, Teacher Andrew shared his ideas in the following lines:

"We need to make or think of teaching strategies. I am teaching confidently but I make sure that I am humble before my students. I am not strict with them. If I will become a 'serious type teacher', my students will not be cooperative; they will not be interested to listen. There is also a tendency that my relationship may be sacrificed and my students will not approach and mingle with me. However, I am stricter when it comes to the assessment period to ensure that they will behave appropriately. My students may cheat if I will not impose the school policy for every assessment period."

Just like Teacher Andrew, Teacher Denver viewed that a good relationship with the students is one of the best ways to solve his problems in teaching. For him, paying attention to students' needs and interests is key. This insight into communication has been shared as follows:

"I manage those problems by setting personal communication with my students. I talk, discuss, and explain with them on their respective levels, and I change my teaching strategies."

In addition, Teacher Bryan, Teacher Chris, and Teacher Esteve emphasized that in teaching Social Studies Subjects, assessing the learning needs or interests of the students is necessary. They also pointed out that the "must be taught" in the curriculum cannot be met when teachers failed to look for the congruency between students' learning interests or need, and the teaching strategies. In this regard, Teacher Bryan said:

"I need to think of the activities that will fit my students' interests and to the target learning competencies. I need to achieve the learning competencies."

As a coping mechanism to teach effectively, the teacher- participants are aware of their roles in curriculum planning. Teacher Esteve mentioned that he set up goals and objectives for every lesson that he has. As it is researched, curriculum planning is well known as an ingredient to successful teaching. 


\subsection{Teachers as Catalysts of Change}

With their line of profession, Social Studies teachers are expected to provide avenues to train their students in the science of citizenship. In this study, they express that they give all their best to ensure effective facilitation of learning. The desire to make changes to mold their students is their inspiration to overcome their challenges and problems in teaching. This idea is noticeable in Teacher Chris's narratives as follows:

"I always believe that my students will be the next professionals in this country. Thus, they need to be trained well and I want to give them a quality education."

Teacher Bryan and Teacher Esteve shared that as teachers, they have to do their duties such as making sure that the desired learning outcomes are met. For them, the learners should be at the center of the curriculum and they have roles beyond being a mere knowledge provider. In their respective accounts, these new graduate teachers mentioned that teaching Social Studies is their passion. They mentioned:

"It is my passion. If you love your work more than your salary, you can overcome every burnout in your chosen profession."

Although some teacher-participants revealed that they are becoming inspired because of their families and personal reasons, the major highlight is still their in-depth concerns to do what is the right thing to do as Social Studies teachers. As the National Council for Social Studies (n.d.) viewed Social Studies Education as a catalyst of change, in his narrative, Teacher Denver shared:

"I do it to bringing the good thing in the World. I believe that I should be a catalyst for change."

\section{Implications and Conclusion}

This qualitative-phenomenological study explored the lived-experiences of new graduate teachers who are teaching secondary Social Studies subjects in one of the provinces in the Philippines. Through the five emerging themes such as (a) the teachers' burden, (b) lack of pedagogical content knowledge, (c) the shortchanged students, (d) the needs-strategies-competencies alignment, and (e) teachers as catalysts of change, the teacher-participants successfully shared their problems and challenges, effects of the problems on the teaching-learning process, their coping mechanisms, and inspirations to perform their duties as teachers of citizenship education.

The finding that there is a lack of instructional materials supports what other researchers presented about the problems in the public schools in Quezon Province. Luzano (2019) and Combalicer (2016) recently found out that the lack of instructional materials hinders the effective facilitation of the learning process. It only implies that the school administrators of the schools need to create plans to solve this problem. They can ask the help of community stakeholders to help them complete their needed materials in teaching or think of viable ways on how to augment their resources. Another problem that emerged in this study is the lack of pedagogical content knowledge among new graduate teachers. Here, the research-participants shared that their students are inattentive and do not give so much attention to Social Studies. Due to this, the students may not learn the desired competencies. Therefore, the school administrators need to mentor and train their teachers on pedagogy and content. Also, they can motivate their teachers to enroll in 
graduate school or take other professional education development courses. In the interviews, the teacherparticipants shared that they have developed conceptual solutions for their problems in teaching Social Studies subjects. With this, school administrators need to provide reinforcement activities to support the teachers to construct their coping mechanisms and to design a better learning environment for learners. These strategies may help the teachers to effectively carry out instruction and ensure that students are trained in the science of citizenship.

Social Studies Education has enabled so many lives to change and is used to mold citizens to become skilled and responsible citizens (Bayir, 2016). Also, Crisolo, Camposano, and Rogayan (2017) reported that Social Studies Education revives communities through awareness for diversity, development, and participation. Thus, Social Studies teachers should be reinforced with good teaching values to ensure that their dream of becoming "catalyst of change" is reached. Finally, schools, colleges, and universities that offer Teacher Education Programs should review their existing programs and continuously seek to provide quality education specifically for Social Studies Education.

\section{Declaration of Conflicting Interests}

The authors declared no potential conflicts concerning the research, authorship, and/or publication of this article.

\section{Funding}

The authors received no financial support for the authorship, research, and/or publication of this article.

\section{References}

Akengin, H., \& Cendek, M. E. (2017). A study of students' opinions about history subjects in the Social Studies curriculum. Journal of Literature and Art Studies. doi:10.17265/2159$5836 / 2017.10 .016$

Akman, O. (2016). The importance of using archive in Social Studies Education. Research Highlights in Education and Science. Retrieved from https://www.isres.org/books/chapters/RHES20164_10-09-2017.pdf

Alabas, R. (2018). Study on the first appearance of Social Studies in the elementary school program in Turkey . International Education Studies. doi:10.5539/ies.v11n11p95

Astalin, P. K. (2013). Qualitative research designs: A conceptual framework. International Journal of Social Science \& Interdisciplinary Research. Retrieved from https://pdfs.semanticscholar.org/baa7/c8f5577b0b1798b5e9f559f5cbae32bf1a36.pdf

Basilan, M. L. (2018). Scantiness of instructional materials in senior high school: Basis for a proposed digital instructional archive. Asia Pacific Journal of Multidisciplinary Research, 6. Retrieved from http://www.apjmr.com/wp-content/uploads/2018/07/APJMR-2018.6.2.2.11.pdf

Bayir, O. G. (2016). The role of Social Studies course in creating society with skilled citizens: Preservice elementary teachers express their views. Turkish Online Journal of Qualitative Inquiry. doi:10.17569/tojqi.39722

Berson, M. J., Cruz, B. C., Duplass, J. A., Johnston, J. H., \& Adler, S. A. (2002). Social Studies Education . Retrieved May 6, 2019, from 
https://www.encyclopedia.com/education/encyclopedias-almanacs-transcripts-andmaps/social-studies-education

Bevan, M. T. (2014). A method of phenomenological interviewing. Qualitative Health Research. doi:10.1177/1049732313519710

Biku, T., Demas, T., Woldehawariat, N., Getahun, M., \& Mekonnen, A. (2018). The effect of teaching without pedagogical training in St. Paul's Hospital Millennium Medical College, Addis, Ababa, Ethiopia. Advances in Medical Education and Practice. doi:10.2147/AMEP.S167944

Bilbao, P. P., Lucido, P. I., Iringan, T. C., \& Javier, R. B. (2008). Curriculum development. Philippines: Lorimar Publishing, Inc.

Borhaug, K., \& Borgund, S. (2018). Student motivation for Social Studies - Existential exploration or critical engagement. Journal of Social Science Education. doi:10.4119/UNIBI/jsse-v17-i4-902

Eberly Center (2019). Students lack interest or motivation. Retrieved from https://www.cmu.edu/teaching/solveproblem/strat-lackmotivation/index.html

Colceru, E. (2013). The impact of civic education on the citizenship of Romanian youth. Journal of Social Science Education, 12. Retrieved from https://www.researchgate.net/publication/307765721_The_Impact_of_Civic_Education_on_th e_Citizenship_of_Romanian_Youth/link/57d7f3ef08ae5f03b4982fe3/download

Combalicer, L. (2016). Best practices and problems in the initial implementation of the $\mathrm{K}+12$ Currciulum among teachers in Infanta, Quezon: Implications to an effective implementation of Senior High School. Journal of Education and Social Science, 4, 1-17.

Corden, A., \& Sainsbury, R. (2006). Using verbatim quotations in reporting qualitative social research: researchers' views. Retrieved from https://www.york.ac.uk/inst/spru/pubs/pdf/verbquotresearch.pdf

Regional Development Council of CaLaBaRZon. (2018). CaLaBaRZon regional development research agenda 2018-2022. Philippine Government. Retrieved from http://calabarzon.neda.gov.ph/wpcontent/uploads/2018/08/RDRA2018-2022.pdf

Crisolo, O. R., Camposano, S., \& Rogayan, D. V. (2017). Relevance of Social Studies in the 21st century society: Students' perspective. ResearchGate. Retrieved from https://www.researchgate.net/publication/317341173_Relevance_of_social_studies_in_the_21 st_century_society_Students'_perspectives

Cropley, A. J. (2019, $2^{\text {nd }}$ updated, revised, and enlarged edition). Qualitative research methods: A practice-oriented introduction for students of psychology and education. Riga, Latvia:Zinātne.

Darling-Hammond, L. (2000). Teacher quality and student achievement: A review of state policy evidence. Education Policy Analysis Archives . Retrieved from https://www.researchgate.net/publication/49609974_Teacher_Quality_and_Student_Achieve ment/download

De Leon, H. S., \& De Leon, H. M. (2014). Textbook on the Philippine Constitution. The Author. "Removed for Peer-Review".

Dislen, G. (2013). The reasons of lack of motivation from the students' and teachers' voices. The Journal of Academic Social Science. Retrieved from https://www.researchgate.net/publication/308792361_the_reasons_of_lack_of_motivation_fro m_the_students'_and_teachers'_voices

Dowling, M. (2007). From Husserl to Van Manen: A review of different phenomenological approaches. Intenrational Journal of Nursing Studies. Retrieved from https://www.researchgate.net/publication/7360690_From_Husserl_to_Van_Manen_A_review _of_different_phenomenological_approaches/link/59e5baa7a6fdcc1b1d96cb1e/download

Department of Education (2013). K to12 gabay pangkurikulum Araling Panlipunan: Baitang 1-10. Retrieved from https://www.deped.gov.ph/wp-content/uploads/2019/01/AP-CG.pdf Department of Education (2016). Adoption of the Basic Education Research Agenda. Retrieved from https://peac.org.ph/wp-content/uploads/2018/08/DO_s2016_039.pdf 
International Journal of Social Sciences \& Educational Studies ISSN 2520-0968 (Online), ISSN 2409-1294 (Print), December 2019, Vol.6, No.2

Department of Education (2017). National adoption and implementation of the Philippine professional standards for teachers. Retrieved from https://www.deped.gov.ph/wpcontent/uploads/2017/08/DO_s2017_042-1.pdf

Grossoehme, D. H. (2014). Overview of qualitative research. Journal of Health Care Chaplaincy. doi:10.1080/08854726.2014.925660।

Hannah, R. (2013). The effect of classroom environment on student learning . Lee Honors College. Retrieved from http://renketkisi.com/en/docs/eng/The\%20Effect\%20of\%20Classroom\%20Environment\%20o n\%20Student\%20Learning.pdf

Henry, G. T., Paterson, K. M., Campbell, S. L., \& Yi, P. (2013). UNC teacher quality research: 2013 teacher preparation program effectiveness report. Chapel Hill, NC: Education Policy Initiative at Carolina. Retrieved from https://publicpolicy.unc.edu/files/2013/11/UNC_TQR_OverallProgramReport_Final.pdf Hudson, S. M., Hudson, P., Weatherby-Fell, N.L., \& Shipway, B. (2016). Graduate standards for teachers: Final-year preservice teachers potentially identify the gaps. Australian Journal of Teacher Education. Retrieved from http://ro.ecu.edu.au/ajte/vol41/iss $9 / 8$

Ingersoll, R., Merrill, L., \& May, H. (2014). What are the effects of teacher education and preparation on beginning teacher attrition?: Research report. Consortium for Policy Research in Education. Retrieved from http://www.cpre.org/sites/default/files/researchreport/2018_prepeffects2014.pdf

Kece, M. (2013). Problems related to the teaching of Social Studies and suggestions for solution: Teachers' opinions based on a qualitative research. 2nd World Conference on Design, Arts and Education DAE. doi:10.1016/j.sbspro.2014.01.1359

Kenyon, E. (2018). Troubled belonging: Lived experience and the responsibility of citizenship. The Journal of Social Studies Research. Retrieved from https://www.sciencedirect.com/science/article/pii/S0885985X17301250?via\%3Dihub

Kılıçoglu, A. (2018). Qualitative Research for Educational Science Researchers: A Review of An Introduction to Qualitative Research. The Qualitative Report, 23(4), 949-951. Retrieved from https://nsuworks.nova.edu/tqr/vol23/iss4/16

Kıliçoğlu, G. (2018). Study on the relationship between Social Studies course self-efficacy and motivation levels of secondary school students. Universal Journal of Educational Research. doi:10.13189/ujer.2018.060816

Kilinç, E., Kilinç, S., Kaya, M., Başer, E., Türküresin, H., \& Kesten, A. (2016). Teachers' attitudes toward the use of technology in social studies teaching. Research in Social Sciences and Technology, 1(1). Retrieved from https://www.ressat.org/index.php/ressat/article/view/6

Kopish, M. (2016). Preparing Globally Competent Teacher Candidates Through Cross Cultural Experiential Learning. Journal of Social Studies Education Research, 7(2), 75-108.

Lopez, N., \& Irene, E. (2018). Motivation and commitment to teaching among pre-service teachers of a State University in Samar, Philippines. Journal of Academic Research. Retrieved from https://www.researchgate.net/publication/322714144_Motivation_and_Commitment_to_Teac hing_among_Pre-service_Teachers_of_a_State_University_in_Samar_Philippines

Luzano, J. (2019). Problems encountered by selected senior high school students in the implementation of the Senior High School Curriculum in a selected school in Infanta, Quezon.

Mathe, N. E., \& Elstad, E. (2018). Students' perceptions of citizenship preparation in Social Studies: The role of instruction and students' interests. Journal of Social Science Education . doi:10.4119/UNIBI/jsse-v17-i3-1779.

Memisoglu, H. (2017). Opinions of teachers and preservice teachers of social studies on geo-literacy. Educational Research and Review. doi:10.5897/ERR2017.3315

Memisoglu, H. (2017). Opinions of teachers and preservice teachers of social studies on geo-literacy. Academic Journals. doi:10.5897/ERR2017.3315 
International Journal of Social Sciences \& Educational Studies ISSN 2520-0968 (Online), ISSN 2409-1294 (Print), December 2019, Vol.6, No.2

Milutinović, J. (2009). Educational progressivism: Theory and practice. Zbornik Instituta za pedagoska istrazivanja. doi:10.2298/ZIPI0902264M

Morse, J. M., Barrett, M., Mayan, M., Olson, K., \& Spiers, J. (2002). Verification strategies for establishing reliability and validity in qualitative research. International Journal for Qualitative methods. Retrieved from https://sites.ualberta.ca/ iiqm/backissues/1_2Final/pdf/morseetal.pdf

Moustakas, C. (1994). Phenomenological research methods. Sage Publications. Retrieved from http://www.psyking.net/HTMLobj-3856/Moustakas.Phenomenological_Theory.pdf

Ochanji, M. K., Chen, R., Daniels, E., Deringer, M. L., McDaniel, J., Stowell, L., \& Cambra-Adamson, C. (2016). A different kind of kid, a different kind of teacher education: Middle grades teachers reflect on their preparation to teach young adolescents. Middle Grades Review. Retrieved from https://files.eric.ed.gov/fulltext/EJ1154923.pdf

Ogaga, G. A., Wallace, I., \& Egbodo, B. A. (2016). Effects of instructional materials on the teaching and learning of social studies in secondary schools in Oku Loal Government are of Benue State. International Journal of Current Research. Retrieved from https://www.researchgate.net/publication/305655450_effects_of_instructional_materials_on_t he_teaching_and_learning_of_social_studies_in_secondary_schools_in_oju_local_governmen t_area_of_benue_state/download

Okechukwu, A. (2015). Coping with the challenges of the teaching profession. Retrieved from https://www.researchgate.net/publication/281177690_coping_with_the_challenges_of_the_tea ching_profession/download

Onwuegbuzie, A. J., \& Collins, K. M. T. (2007). A typology of mixed methods sampling designs in Social Science research . The Qualitative Report. Retrieved from https://nsuworks.nova.edu/cgi/viewcontent.cgi?article=1638\&context=tqr

Palinkas, L. A., Horwitz, S. M., Green, C. A., Wisdom, J. P., Duan, H., \& Hoagwood, K. (2015). Purposeful sampling for qualitative data collection and analysis in mixed method implementation research. doi:10.1007/s10488-013-0528-y.

Rice, J. K. (2003). Teacher quality: Understanding the effectiveness of teacher attritbutes. Retrieved from https://eric.ed.gov/?id=ED480858

Samuel, A. W. (2009). The importance of instructional materials in our schools an overview. Retrieved from https://www.researchgate.net/publication/322368912_THE_IMPORTANCE_OF_INSTRUCT IONAL_MATERIALS_IN_OUR_SCHOOLS_AN_OVERVIEW/link/5a5658c30f7e9bf2a536 c302/download

Schug, M. C., Todd, R. J., \& Beery, R. (1982). Why kids don't like Social Studies. National Council for Social Studies. Retrieved from https://files.eric.ed.gov/fulltext/ED224765.pdf

Shaughnessy, J. M., \& Haladyna, T. M. (1985). Research on student attitude toward Social Studies. Retrieved from https://www.researchgate.net/signup.SignUp.html?ev=su_requestFulltext

Solhaug, T., \& Børhaug, K. (n.d.). Skolen i demokratiet - demokratiet i skolen.

Studies, N. C. (n.d.). What Is Social Studies? Retrieved from https://www.learner.org/workshops/socialstudies/pdf/session1/1.WhatIsSS.pdf

Szucs, I. Z. (2017). What make a good teacher? Universal Journal of Educational Research Vol. 5(1), 141 - 147. doi:10.13189/ujer.2017.050118.

Tannebaum, R. P. (2015). Preservice Social Studies Teachers' Perspectives and Understandings of Teaching in the Twenty-First Century Classroom: A Meta-Ethnography. Journal of Social Studies Education Research. Retrieved from https://files.eric.ed.gov/fulltext/EJ1105365.pdf

Tena, J. C. (2019). Instruction and assessment of Araling Panlipunan teachers in Paaralang Sekundarya ng Heneral Nakar: Implications to Effective Teaching and Learning. Master's Thesis.

Terronez, A. (2017). What makes a good teacher great? Retrieved from https://www.youtube.com/watch?v=vrU6YJle6Q4 
Ulla, M. (2016). Pre-service teacher training programs in the Philippines: The student-teachers practicum teaching experience. EFL Journal. doi:http://dx.doi.org/10.21462/eflj.v1i3.23

Vaismoradi, M., Jones, J., Turunen, H., \& Snelgrove, S. (2016). Theme development in qualitative content analysis and thematic analysis. Journal of Nursing Education and Practice. doi:10.5430/jnep.v6n5p100

Williams, M. K. (2017). John Dewey in the 21 st Century. Journal of Inquiry \& Action in Education. Retrieved from https://files.eric.ed.gov/fulltext/EJ1158258.pdf 